\title{
Magnitude and fate of the production of four co- occurring Western Mediterranean seagrass species
}

\author{
Just Cebrián ${ }^{1, *}$, Carlos M. Duarte $^{2}$, Nùria Marbà ${ }^{3}$, Susana Enríquez $^{4}$ \\ ${ }^{1}$ Boston University Marine Program, Marine Biological Laboratory, Woods Hole, Massachusetts 02543, USA \\ ${ }^{2}$ Centro de Estudios Avanzados de Blanes (CSIC), Cami de Santa Bàrbara s/n, E-17300 Blanes (Girona), Spain \\ ${ }^{3}$ Netherlands Institute of Ecology, Centre for Estuarine and Coastal Ecology, Vierstraat 28, 4401 EA Yerseke, The Netherlands \\ ${ }^{4}$ The Freshwater Biological Laboratory, University of Copenhagen, Helsingørsgade 51, DK-3400 Hillerød, Denmark
}

\begin{abstract}
We examined the seasonality and magnitude of the leaf-blade, rhizome and root biomass and production, along with the fate of leaf-blade production, of the 4 Mediterranean seagrass species Posidonia oceanica, Cymodocea nodosa, Zostera noltii and Zostera marina in a protected northern Spanish bay (Cala Jonquet, $42^{\circ} 18.26^{\prime} \mathrm{N}, 3^{\circ} 18.11^{\prime} \mathrm{E}$ ) to estimate (1) the annual production consumed by herbivores or decomposed by detritivores and (2) the production in excess of consumption and firstyear decomposition, which should be an upper limit of long-term burnal of refractory detritus. The leaf, rhizome and root biomass of the 4 species displayed a clear seasonal pattern (which is in agreement with past studies), except for that of $Z$. noltii, which suggested a rapid loss of its production either to herbivores or as detritus. Z. marina and $P$. oceanica were the most productive species, and transferred to consumers (herbivores and detritivores) about twice the production transferred by $C$. nodosa and $Z$. noltii. Most of the production of the 4 species was decomposed by detritivores, which supports the importance of the detritivore food-web in the use and recycling of seagrass production. Consumption of seagrass leaf production by herbivores appeared to be higher for $C$. nodosa and $Z$. noltii, the species with the greatest leaf tumover rates, than for $Z$. marina and $P$. oceanıca. Total heterotrophic use of seagrass production (consumption by herbivores and decomposition by detritivores) accounted for more than $80 \%$ of seagrass production in the 4 species. Yet, the excess of production not consumed nor decomposed during the first year ranged over 1 order of magnitude from the most $(Z$. marina and $P$. oceanica) to the least productive species ( $C$. nodosa and $Z$. noltii) and represented a larger percentage of the production of the former species $\{9.2$ and $16.8 \%$ respectively) compared with the latter species (about $1.5 \%$ ). That suggests that $Z$. marina and $P$. oceanica may accumulate larger pools of refractory detritus and that their production is recycled more slowly than that of $C$. nodosa and $Z$. noltii. These results show marked differences in the fate of production among the 4 Western Mediterranean seagrass species growing in Cala Jonquet and suggest that differences in the leaf turnover rate could contribute to the explanation of differences in the fate of seagrass production, the species with fastergrowing leaves losing a higher percentage of production to herbivores and recycling most of the residual detrital production, therefore storing relatively small pools of refractory detritus.
\end{abstract}

KEY WORDS: Mediterranean seagrasses - Fate of production - Herbivory - Decomposition Production excess

\section{INTRODUCTION}

Seagrass meadows may be highly productive and therefore may have a strong bearing on the trophic dynamics of many coastal ecosystems (Zieman 1982, Thayer et al. 1984). Seagrasses are key components of such meadows and hence examination of the trophic

•E-mail: jcebrian@mbl.edu routes through which seagrass production is transferred to higher trophic levels is crucial to understanding the role of seagrass meadows in the trophic web of coastal ecosystems. The seagrass production consumed by herbivores and decomposed by detritivores determines all secondary production supported by seagrasses themselves within the meadow or elsewhere when carried out by waves and currents (Thayer et al. 1984, Bach et al. 1986). Conversely, the production 
buried in the sediment as refractory detritus involves a net loss for heterotrophic use and represents the seagrass' capacity to act as a sink for organic carbon (Hemminga et al. 1991, Romero et al. 1994). Hence, seagrasses with simila levels of production may play different trophic roles, depending on what proportion of production follows which of the available routes, and can have, therefore, contrasting trophic implications in the ecosystem.

The fate of seagrass production seems to differ substantially among species. For instance, Halophila ovalis and Halodule uninervis often support intense consumption by dugongs (cf. Sheppard et al. 1992, De longh et al. 1995) while herbivory only accounts for a minor percentage of the production of other species (e.g. Posidonia oceanica; Ott \& Maurer 1977, Velimirov 1984, Cebrián et al. 1996a). Moreover, some species develop thick rhizomes and roots with associated low decay rates and consequently store large pools of refractory detritus (for instance: $P$. oceanica, Romero et al. 1994; Thalasodendron sp., Lipkin 1979; Posidonia australis, Shepherd \& Sprigg 1976), in contrast with the much smaller refractory pools for species with faster. turnover rates in their belowground parts (for instance: Cymodocea nodosa, Mateo 1995; Zostera marina, Kenworthy \& Thayer 1984, Pellikaan \& Nienhuis 1988) Furthermore, although the exportation rates of detrital leaves may vary widely, depending on the physical conditions in the meadows, the published values tend to be higher for species with shorter and narrower leaves (for a review of exportation rates, cf. Hemminga et al. 1991, Pergent et al. 1994), probably because of their greater buoyancy and associated susceptibility to transportation by waves and currents. Whereas estimates of seagrass production are abundant (cf. Duarte 1989, Hillman et al. 1989), estimates of the fate of seagrass production are still few (Duarte \& Cebrián 1997).

Four seagrass species grow in the Western Mediterranean Sea. Posidonia oceanica (L.) Delile is the dominant species, developing extensive, productive meadows that play an important ecological role (Wittmann 1984). Cymodocea nodosa (Ucria) Ascherson dominates in some sheltered bays and coastal lagoons, and it forms dense meadows at considerable depth (e.g. 8 to $20 \mathrm{~m}$ on the northern Spanish Mediterranean coast and $>30 \mathrm{~m}$ at the Balearic Islands and Malta; Ballesteros et al. 1989), whereas Zostera noltii Hornem and $Z$. marina $L$. are much less frequent and are confined to a few sheltered environments (Ballesteros et al. 1989). Production in the Mediterranean has been evaluated for $P$. oceanica, $C$. nodosa and $Z$. noltii, but not for $Z$. marina. Moreover, the fate of the production of these 4 species is little known, with only some reports of herbivory on $P$ oceanica (cf. Ott \& Maurer 1977, Velimirov 1984, Cebrián et al. 1996a) and on C. nodosa (Cebrián et al. 1996b) and some reports of burial and export of $P$. oceanica (Romero et al. 1992, Pergent et al 1994), and of C. nodosa (Mateo 1995) production being available. Hence, there is a need to assess and compare the fate of production of these 4 species in order to characterise their trophic role in Mediterranean coastal ecosystems.

The co-occurrence of the 4 Western Mediterranean seagrass species in a sheltered bay (Cala Jonquet) on the northern Spanish Mediterranean coast allows comparison of the magnitude and fate of their production under similar environmental conditions. In this report, we assess the seasonality and magnitude of the leafblade, rhizome and root production of these 4 species in Cala Jonquet Bay, and analyse the annual leafblade production consumed by herbivores and decomposed by detritivores. Moreover, based on published decay rates of the belowground components of these species, we estimate the belowground production decomposed. We finally combine all these measurements to discuss and compare among the 4 species (1) the total annual production consumed by herbivores or decomposed by detritivores, and (2) the excess of production over consumption and first-year decomposition, which corresponds to an upper limit of the seagrass production buried as refractory detritus

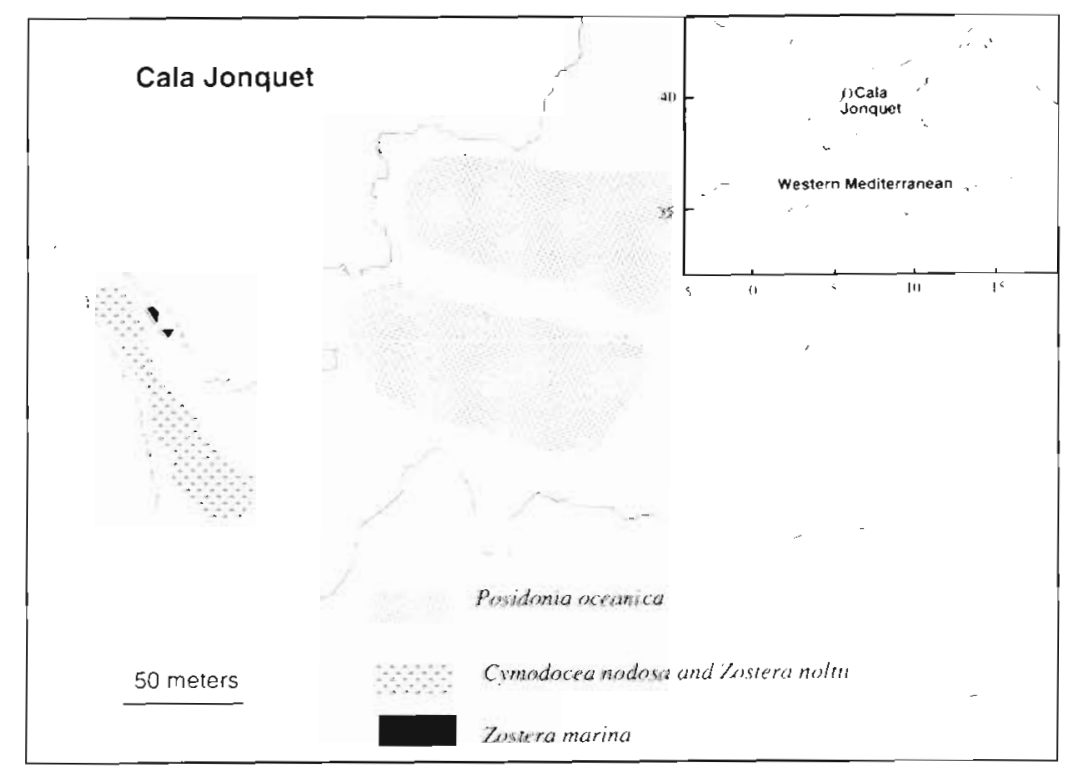

Fig. 1. Locations of the species sampled in Cala Jonquet 


\section{METHODS}

Cala Jonquet is a sheltered bay located on the northern Spanish Mediterranean coast $\left(42^{\circ} 18.26^{\prime} \mathrm{N}, 3^{\circ}\right.$ $18.11^{\prime}$ E) where the 4 Western Mediterranean seagrass species grow (Fig. 1). All the species were sampled at the depth of maximal density, which was $4 \mathrm{~m}$ for Posidonia oceanica and $1 \mathrm{~m}$ for the other 3 species (Marbà et al. 1996a). We visited this bay monthly (bimonthly for some sampling visits) from winter 1991 to summer 1993. On every sampling visit, 3 corers of $20 \mathrm{~cm}$ diameter were randomly pushed about $20 \mathrm{~cm}$ into the sediment within the seagrass patches to collect Cymodocea nodosa and Zostera noltii, from which the density of shoots of the 2 species (i.e. leaf clusters for $Z$. noltii) and horizontal apices of $C$. nodosa were registered. Shoot density of $P$. oceanica and $Z$. marina (i.e. leaf clusters for $Z$. marina) and the density of horizontal apices of $P$. oceanica were estimated from 3 replicated 0.25 and $0.1 \mathrm{~m}^{2}$ quadrats randomly tossed on the $P$. oceanica meadow and the $Z$. marina patches, respectively, due to the toughness of the $P$. oceanica belowground structure and to preserve the small area covered by $Z$. marina (Fig. 1). In addition, 50 to 100 shoots of each of these 2 species along with their attached belowground material were dug out on each visit.

Leaf (blades and attached sheaths), rhizome and root

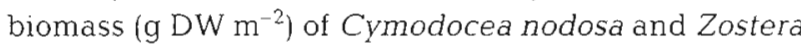
noltii was calculated from the weight of each respective compartment within the corers after the plant material was dried overnight at $80^{\circ} \mathrm{C}$. Leaf biomass of Posidonia oceanica and $Z$. marina was estimated as the product of mean shoot density and the mean ratio of leaf dry weight per shoot, which was derived from the collected sample. Similarly, the rhizome and root biomass of $Z$. marina were calculated as the product of the mean shoot density and the mean ratio of dry weight of horizontal rhizomes or roots per shoot, respectively, which were also derived from the collected sample. This procedure, however, did not allow accurate estimation of the belowground biomass of $P$. oceanica, which penetrates several tens of centimetres into the sediment (Romero et al. 1992, Mateo 1995).

On every visit, we marked 10 to 15 apices of horizontal rhizome of each species and 10 to 15 short shoots of Posidonia oceanica and Cymodocea nodosa as described by Marbà et al. (1996a). That allowed us to derive, for every sampling interval, the horizontal rhizome production rate per apex (g DW apex ${ }^{-1} d^{-1}$ ), the root production rate per apex (g DW apex ${ }^{-1} \mathrm{~d}^{-1}$ ) and the leaf-blade production rate per shoot $\left(g \mathrm{DW}\right.$ shoot $\left.^{-1} \mathrm{~d}^{-1}\right)$, which is also comprehensively described in Marbà et al. (1996a). For every sampling interval, the horizontal rhizome and root production rates $\left(g \mathrm{DW} \mathrm{m}^{-2} \mathrm{~d}^{-1}\right)$ were calculated as the product of the average density of hor- izontal apices and the horizontal rhizome or root production rate per apex, respectively. Likewise, the leafblade production rate ( $g \mathrm{DW} \mathrm{m}^{-2} \mathrm{~d}^{-1}$ ) for every sampling interval was calculated as the product of the corresponding mean shoot density and leaf-blade production rate per shoot. We accounted for the bladegrowth of the leaves shed by senescence between consecutive sampling visits by adding, for each sampling interval, the product of the average number of leaves shed per shoot (see below) and the average bladegrowth of the oldest standing age rank to the corresponding estimate of leaf-blade production per shoot.

We estimated the annual leaf-blade, horizontal rhizome and root production ( $\mathrm{g} D W \mathrm{~m}^{-2} \mathrm{yr}^{-1}$ ) for the 4 species by adding the products of the daily rates and duration of the corresponding sampling intervals over $1 \mathrm{yr}$. Annual leaf turnover was estimated as the ratio of annual leaf production to maximal leaf biomass. The marking technique used to estimate the production of horizontal rhizomes (Marbà et al. 1996a) may have led to significant underestimation for Posidonia oceanica (Pergent 1990, Pergent-Martini et al. 1994), because the internodes appearing during a monthly sampling interval can subsequently exhibit substantial growth. Moreover, this method overlooks the production of vertical rhizome in species with short shoots, i.e. $P$. oceanica and Cymodocea nodosa. Hence we compiled estimates of the annual $P$. oceanica horizontal (Marbà et al. 1996b) and P. oceanica and C. nodosa vertical (Marbà unpubl. data) rhizome production in Cala Jonquet derived from seagrass-growth reconstruction methods (Duarte et al. 1994). The method used for estimation of root production may also result in underestimation (Marbà ét al. 1996a) and was not adequate for P. oceanica (Marbà et al. 1996a). However, because root production typically represents a minor percentage of total seagrass production (cf. Peduzzi \& Vukovic 1990, Sánchez-Lizaso 1993, Van Lent \& Verschuure 1994, Vermaat \& Verhagen 1996), we believe that this does not affect the differences found in the fate of production among the 4 species. The annual production of leaf sheaths was estimated as the product of the annual leaf formation rate, derived from the leaf marking technique (Marbà et al. 1996a), and the mean sheath biomass of the oldest leaves.

The leaf-blade material produced can be incorporated into standing biomass, be consumed by herbivores, be torn off and subsequently float away as a result of wave action and herbivore bites, or eventually be shed following leaf senescence. In turn, the leaf blades sloughed off either by senescence or by wave or herbivore action decompose gradually within the meadow, or out of it when they are exported by waves and currents. These routes determine the fate of leafblade production, which was also estimated in the 
study. The mean number of leaf blades per shoot shed by senescence during each sampling interval $\left(S_{x t}\right)$ was derived from the mean number of standing leaves per shoot at the beginning $\left(N_{t-1}\right)$ and end $\left(N_{t}\right)$ of the sampling interval and the mean number of leaves per shoot born during that sampling interval $\left(B_{.,}\right)$, following the equation (Alcoverro et al. 1995):

$$
S_{\mathrm{X}}=N_{t-1}+B_{M t}-N_{t}
$$

Then, for each sampling period, the rate of leaf-blade shedding by senescence ( $\mathrm{g}$ DW $\mathrm{m}^{-2} \mathrm{~d}^{-1}$ ) was derived as the product of $S_{j,}$ the mean blade biomass of the oldest standing age rank and the mean shoot density during the sampling interval, divided by the duration of the sampling interval in days. We also attempted to include leaf-blade shedding due to shoot mortality in the species which displayed a marked seasonal shoot density (i.e. Zostera marina and Cymodocea nodosa) by adding the product of the difference in shoot density and the average leaf-blade biomass per shoot, divided by the duration of the sampling interval, to the calculation of leaf-blade shedding rates described above for each of the intervals where a significant reduction in shoot density occurred.

Subsequently, the rate of leaf-blade production either consumed by herbivores or torn off by wave action or herbivore bites (i.e. leaf-blade residual loss, $R L$, in $\mathrm{g} D W \mathrm{~m}^{-2} \mathrm{~d}^{-1}$ ) was derived for each sampling interval as:

$$
R L=L P-L S-\Delta L B
$$

where $\triangle L B\left(\mathrm{~g} \mathrm{DW} \mathrm{m} \mathrm{m}^{-2} \mathrm{~d}^{-1}\right)$ is the increment in standing leaf-blade biomass during the sampling interval and $L P$ and $L S\left(\mathrm{~g} \mathrm{DW} \mathrm{m}^{-2} \mathrm{~d}^{-1}\right)$ are the rates of leaf-blade production and shedding by senescence, respectively, measured for the sampling interval. For Posidonia oceanica, the loss of leaf production exclusively due to consumption by herbivores may be readily estimated from the bite marks imprinted on the leaf blade (Cebrian et al. 1996a) That cannot be done for the other 3 species because, due to the relative narrowness of their leaf blades, the number of bite marks present is always low regardless of the intensity of herbivory. Hence, for $P$. oceanica, the biomass of any leaf age rank consumed between 2 consecutive sampling dates was derived from the increment in the surface covered by the bite marks on that age rank during the sampling interval, after transforming leaf surface to biomass by means of the leaf specific weight. Subsequently, the consumption per shoot for every sampling interval was calculated by adding the consumption on each age rank during that interval and expressed per unit area ( $g$ DW $\mathrm{m}^{-2} \mathrm{~d}^{-1}$ ) according to shoot density. Estimates of the annual leaf-blade production shed by senescence and either consumed by herbivores or torn off by wave or herbivore action (g DW $\mathrm{m}^{-2} \mathrm{~d}^{-1}$ ) were also calculated by adding the products of the daily rates and duration of the corresponding sampling intervals over 1 yr

In order to assess the use of detrital leaf blades by detritivores, litter bag experiments (Josselvn et al. 1986) for each species were carried out from May to October 1994, covering the period when most of the leaf-blade shedding by senescence and subsequent decomposition (cf. Figs. 2 \& 4) occurs. These experiments took place in Cala Jonquet for Posidonia oceanicd, but were carried out, due to logistic constraints, in a similar sheltered bay (i.e. protected bay with similar temperature and depth ranges) closer to our laboratory for the other 3 species. The oldest leaf blade of every sampled shoot was selected to best simulate the decomposition of newly shed leaf blades. A known mass of fresh leaf blades was enclosed in mesh bags (1 $\mathrm{mm}^{2}$ pore size), which were just barely buried in the sediment among the standing detrital leaf blades. The dry weight $\left(80^{\circ} \mathrm{C}\right.$ overnight $)$ of the leaf-blade material remaining in triplicate bags collected at increasing time intervals, spanning a whole experimental period of 4 to $5 \mathrm{mo}$, was measured to estimate the decomposition of detrital leaf blades. The rate of disappearance of leaf detrital material was described by fitting a simple negative exponential equation (Olson 1963), using least-squares regression analyses

$$
\ln (\text { fraction of initial dry weight remaining) }=-k \times t
$$

where $k\left(\mathrm{~d}^{-1}\right)$ and $t(\mathrm{~d})$ correspond to the decomposition rate and time elapsed since the beginning of the experiment, respectively. Simple (i.e. linear) exponential models of decomposition assume a constant rate along the entire decay process. Other complex models, such as the double exponential, asymptotic and quadratic equations (Wieder \& Lang 1982), in general did not yield a better fit than the equation employed. Disappearance rates of detrital material measured from litter bags include detritus decay, fragmentation by detritivores, and washing off of detrital particles smaller than the mesh size (Harrison 1989). Since most of these exported small detrital particles undergo decomposition. the disappearance rates measured are indicative of the use of seagrass production by detritivores.

We did not attempt to assess exportation of detrital leaf blades from Cala Jonquet Bay. Although Cala Jonquet is a very shallow, protected bay (Fig 1) which remains calm even during rough sea conditions off the bay, exportation of detrital leaf blades could be significant and differ notably among the 4 species, as demonstrated in other relatively protected bays (Romero et al. 1992, Mateo 1995). Yet, this does not conflict with the aims of this paper, because we intend to compare among the 4 species the extent of seagrass production. 
consumed by herbivores or detritivores, and the excess of annual production escaping from this consumption, regardless of whether these routes take place inside or outside the meadow

The error associated with our estimates of biomass, production and fate of leaf-blade production isee Eqs. 1 \& 2) was derived by techniques of error propagation (Tsokos 1972). Cross correlation analysis, which derives the Pearson correlation coefficient ( $r$ ) at a given time lag between 2 time series, was used to describe the similarity between the seasonal patterns of leaf-blade production and its fate for the 4 species.

\section{RESULTS}

Leaf biomass was seasonal for all species except for Zostera noltii (Fig. 2), with a summer maximum (all values expressed as mean $\pm \mathrm{SE}$ ) of $555.7 \pm 47.1,87.7 \pm$ 7.4 and $291.3 \pm 40.6 \mathrm{~g} \mathrm{DW} \mathrm{m}^{-2}$ for $Z$. marina, Cymodocea nodosa and Posidonia oceanica, respectively. Minimum leaf biomass occurred in winter and averaged $1.5 \pm 0.5,10.3 \pm 0.9$ and $183.5 \pm 16.4 \mathrm{~g} \mathrm{DW} \mathrm{m}^{-2}$ for these 3 species, respectively. Conversely the leaf biomass of $Z$. noltii varied over an order of magnitude throughout the sampling period (from $<1$ to $44 \mathrm{~g} \mathrm{DW}$ $\mathrm{m}^{-2}$ ) with no clear seasonal pattern (Fig. 2). Rhizome and root biomass did not follow, on the whole, a clear seasonal pattern (Fig 3). Only the rhizome and root biomass of $Z$. marina, and the rhizome biomass of $C$ nodosa exhibited a marked peak in summer, reaching, respectively, $213.1 \pm 18.1$ and $175.1 \pm 6.6 \mathrm{~g} \mathrm{DW} \mathrm{m}^{-2}$ for Z. marina and $330.5 \pm 46.2 \mathrm{~g} \mathrm{DW} \mathrm{m}^{-2}$ for $C$. nodosa (Fig. 3).

In contrast, leaf-blade, horizontal rhizome and root production rates were seasonal for all species except for the rhizome of Posidonia oceanica (Figs. 2 \& 3) Maximal leaf-blade, horizontal rhizome and root production rates occurred in summer, except for the maximal leaf-blade production rate of $P$. oceanica, which occurred in winter and spring, and that of Zostera noltii, which occurred in autumn (Fig. 2). Maximal leaf-blade production rates amounted to $8.2 \pm 2.4,4.5 \pm$ $1.3,2.6 \pm 0.7$ and $3.2 \pm 0.7$ (for both peaks in winter and spring) $g$ DW m $\mathrm{m}^{-2} \mathrm{~d}^{-1}$ for $Z$. marina, Cymodocea nodosa, $Z$. noltii and $P$. oceanica, respectively (Fig. 2) The horizontal rhizome and root production rates peaked at $2.1 \pm 0.7$ and $1.1 \pm 0.6$ for $Z$. marina, $0.9 \pm$ 0.3 and $1.8 \pm 0.6$ for $C$. nodosa and $1.2 \pm 0.6$ and $0.33 \pm$ $0.17 \mathrm{~g} \mathrm{DW} \mathrm{m}^{-2} \mathrm{~d}^{-1}$ for Z. noltii (Fig. 3).

Annual production values for leaf blades and sheaths showed a range of more than 2 -fold between the least (Zostera noltii) and the most productive ( $Z$. marina) species (Table 1 ). The species with higher annual production of blades and sheaths ( $Z$. marina and $P$. ocean- ica) supported maximal leaf biomasses disproportionately greater than those supported by the species with lower annual production ( $C$. nodosa and $Z$. noltii), which resulted in much slower leaf turnover rates for the former species (Table 1). Although root production of $P$. oceanica is not accounted for, and because this production only represents a minor fraction of total $P$. oceanica production (see Table 2), our measurements showed that annual production of rhizomes and roots varied notably among the 4 species, being highest for $Z$. marina. Annual total production was highest for $Z$. marina, which was $1 \frac{1}{2}, 2$ and 3 times that of $P$. oceanica, C. nodosa and $Z$. noltii, respectively (Table 1 ).

The seasonal dynamic of leaf-blade shedding by senescence closely matched that of leaf-blade production (except for that of Posidonia oceanica) with maximum shedding either coinciding (Zostera noltii, time $\operatorname{lag}=0 \mathrm{mo}, \mathrm{r}=0.93, \mathrm{p}<0.05)$ or closely following $(Z$. marina and Cymodocea nodosa, time lag $=1 \mathrm{mo}, \mathrm{r}=$ 0.79 and 0.92 , respectively, $p<0.05$ ) maximum production (Fig. 2). Most of the leaf-blade shedding of $P$. oceanica occurred in autumn (Fig. 2). The amount of annual leaf-blade production falling away with senescence varied about 3 -fold among the 4 species (Table 1), but it represented a fairly uniform percentage of the annual leaf-blade production (ca $60 \%$ ) for all 4 species (Table 1 ).

The seasonal dynamic of the leaf-blade residual loss was associated with that of production for Zostera marina and Cymodocea nodosa (time lag $=1$ and $0 \mathrm{mo}$, $r=0.79$ and 0.91 , respectively, $p<0.05$ for both coefficients), whereas this loss displayed an irregular temporal pattern for Posidonia oceanica and Z. noltii (Fig. 2) Annual leaf-blade residual loss also varied about 3 fold among the 4 species, representing from 25 to $40 \%$ of the annual leaf-blade production (Table 1). Herbivore consumption rates for $P$. oceanica leaves ranged from negligible to $0.3 \mathrm{~g} \mathrm{DW} \mathrm{m}^{-2} \mathrm{~d}^{-1}$, and only represented about $5 \%$ of the annual leaf-blade residual loss

The decomposition of detrital leaf blades followed a simple negative exponential curve for the 4 species studied (Fig 4). Leaf blades of Zostera marina and Cymodocea nodosa decayed faster $(k=0.0189 \pm$ $0.0016 \mathrm{~d}^{-1}$ and $0.0236 \pm 0.0045 \mathrm{~d}^{-1}$, respectively) than those of Posidonia oceanica $\left(k=0.0091 \pm 0.001 \mathrm{~d}^{-1}\right.$, $t$-test, $H_{0}$ : equality between $k, \mathrm{p}<0.05$ ). The decay rate for the detrital leaf blades of $Z$. noltii was intermediate $\left(k=0.0146 \pm 0.0026 \mathrm{~d}^{-1}\right)$ and did not differ from the rest of species $(\mathrm{p}>0.05)$.

\section{DISCUSSION}

The production of leaf blades, horizontal rhizomes and roots of the 4 seagrass species followed a seasonal 

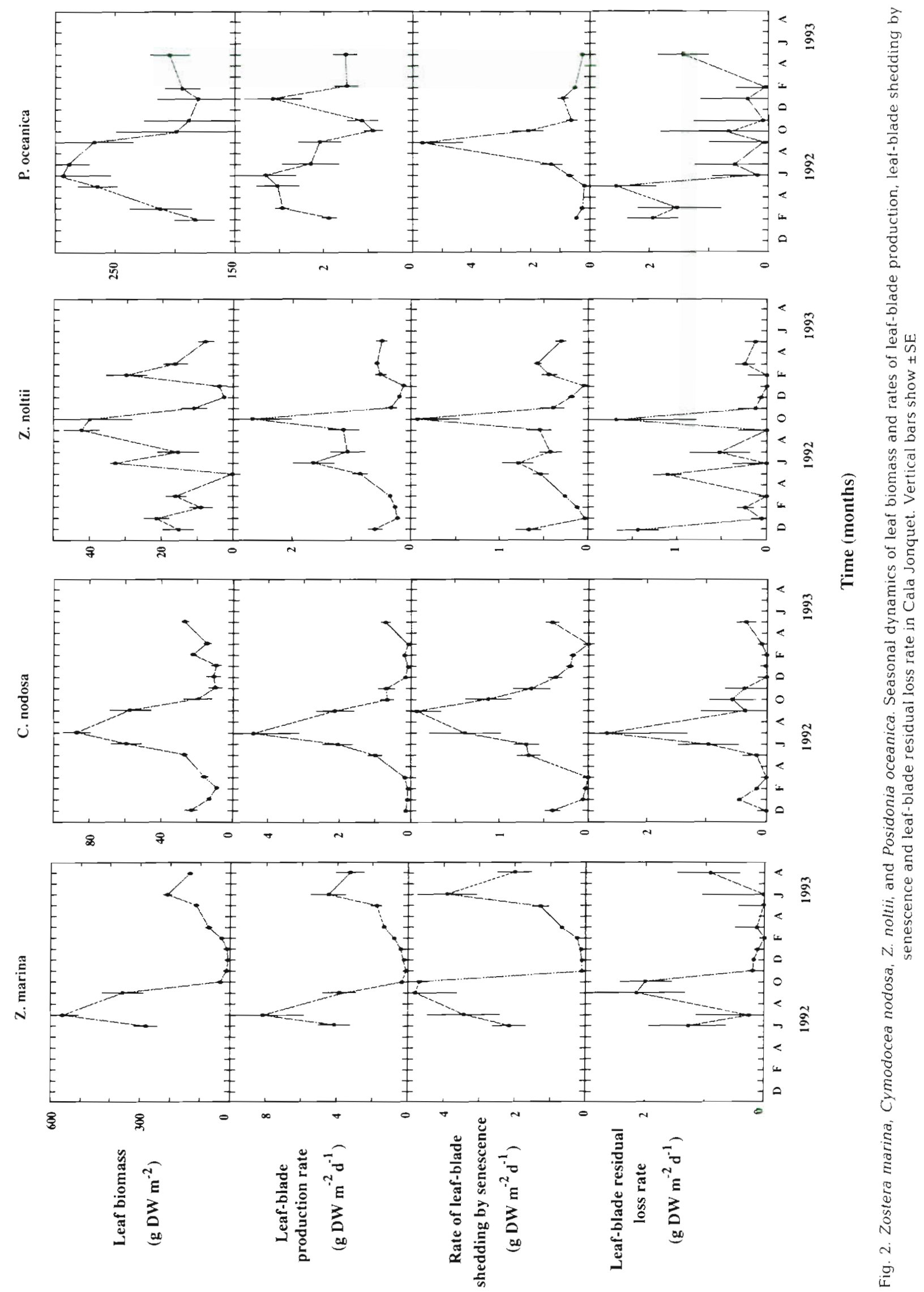

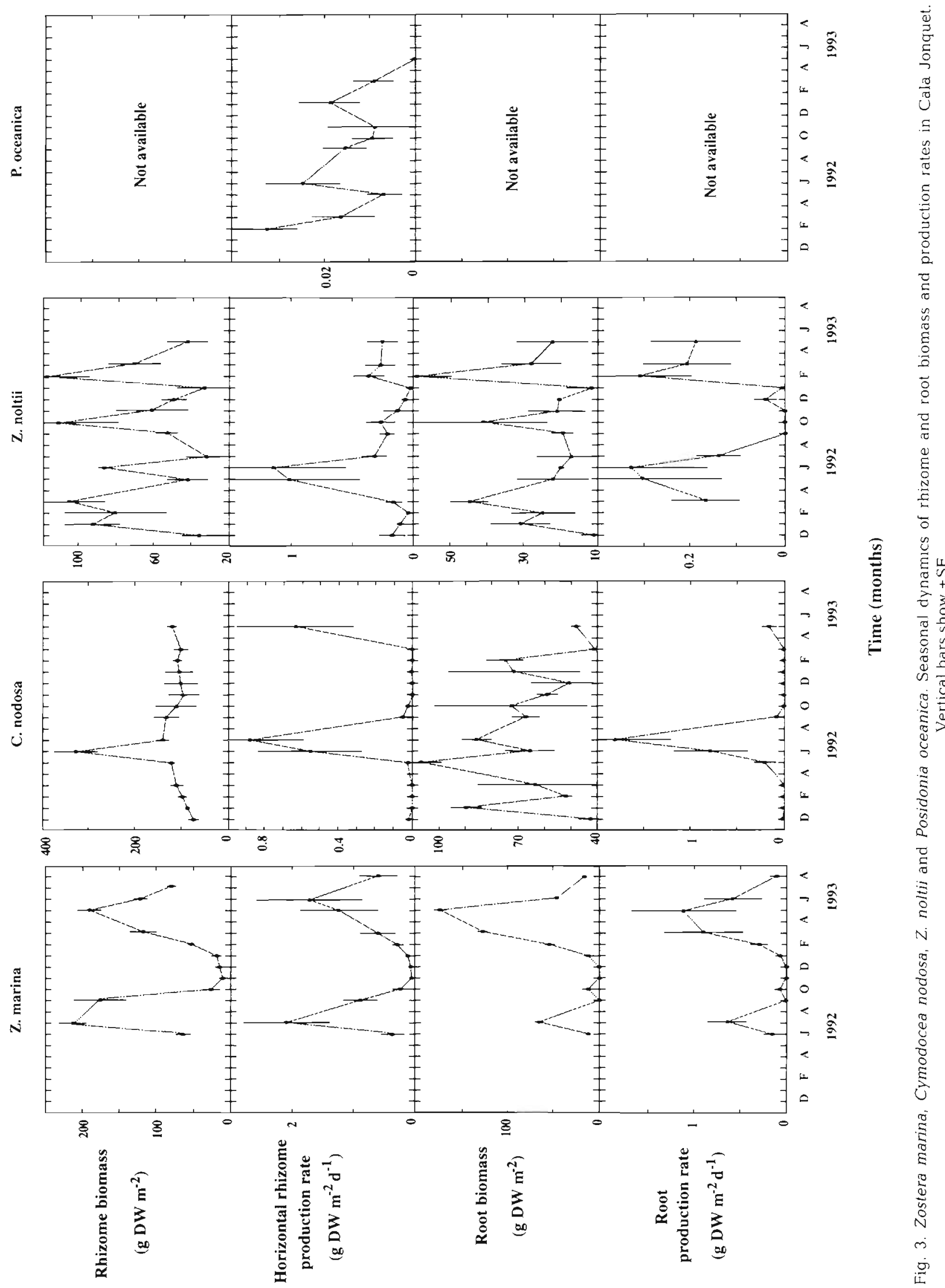
Table 1, Zostera marina, Cymodocea nodosa, Z. noltir and Posidonia oceanica. Biomass (g DW $\mathrm{m}^{2} \mathrm{~h}$ and production $\left(\mathrm{g}\right.$ DW $\mathrm{m}^{-2}$ $\mathrm{yr}^{-1}$ ) values and turnover rates (y $\mathrm{r}^{-1}$ ) for the 4 seagrass species studied. Values in parentheses show the percentage of annual leafblade production accounted for. Note that, because of the associated error, the sum of the annual estimates of leaf shedding by senescence and residual loss do not have to coincide with the annual estimate of leaf-blade production. nd: no data

\begin{tabular}{|c|c|c|c|c|}
\hline & 2. marina & C. nodosa & Z noltii & P. oceanica \\
\hline Maximal leaf biomass & $555.7 \pm 47.1$ & $87.7 \pm 7.4$ & $42.9 \pm 4.8$ & $291.2 \pm 40.6$ \\
\hline Leaf-blade production & $874.5 \pm 202.7$ & $475.6 \pm 120.9$ & $291.8 \pm 69.1$ & $845.3 \pm 144.4$ \\
\hline Leaf-sheath production & 146.4 & 64.8 & 110.5 & 80.6 \\
\hline Leaf blade + sheath production & 1020.9 & 540.4 & 402.3 & 925.9 \\
\hline Leaf turnover rate & 18 & 6.2 & 9.4 & 3.2 \\
\hline Horizontal rhizome production & $259.2 \pm 89.2$ & $65.5 \pm 25.1$ & $117.1 \pm 58.6$ & $\begin{array}{c}6.5 \pm 2.3 \\
42.9^{\circ}\end{array}$ \\
\hline Vertical rhizome production & & $17.9^{b}$ & & $20.5^{b 3}$ \\
\hline Root production & $145.4 \pm 62.9$ & $120 \pm 24.5$ & $47.4 \pm 25.2$ & nd \\
\hline Rhizome + root production & $404.6 \pm 152.1$ & 203.4 & $164.5 \pm 83.8$ & $63.4^{r}$ \\
\hline Total production & 1425.5 & 743.8 & 566.8 & 989.3 \\
\hline Leaf-blade shedding by senescence & $\begin{array}{c}568.4 \pm 131.1 \\
(65)\end{array}$ & $\begin{array}{c}258.2 \pm 63.9 \\
(54.3)\end{array}$ & $\begin{array}{c}188.1 \pm 4.3 .9 \\
(64.4)\end{array}$ & $\begin{array}{c}500.3 \pm 102.3 \\
(59.2)\end{array}$ \\
\hline Leaf-blade residual loss & $\begin{array}{c}228.3 \pm 79.9 \\
(26.1)\end{array}$ & $\begin{array}{c}211.4 \pm 98.3 \\
(44.4)\end{array}$ & $\begin{array}{c}120.4 \pm 40.5 \\
(41.3)\end{array}$ & $\begin{array}{c}300.2 \pm 80.5 \\
(35.5)\end{array}$ \\
\hline \multicolumn{5}{|c|}{$\begin{array}{l}\text { "Value calculated from seagrass-growth reconstructing techniques (Duarte et al. 1995) by Marbà et al. (1996b). This value } \\
\text { was used in estimatıng the total (horizontal + vertical) annual rhizome production value shown here } \\
\text { bulues calculated from seagrass-growth reconstructing techniques (Duarte et al. 1995) by Marbà (unpubl. data) } \\
\text { 'Only annual rhizome production }\end{array}$} \\
\hline
\end{tabular}

pattern (Figs. $2 \& 3$ ) similar to that reported in the past (see references in Table 2). The only exception was the horizontal rhizome production of Posidonia oceanica, which fluctuated little at about $0.02 \mathrm{~g} \mathrm{DW} \mathrm{m}^{-2} \mathrm{~d}^{-1}$ (Fig. 3), in agreement with previous reports of weak seasonality in $P$. oceanica belowground growth (Wittmann 1984). The lack of seasonality of $P$. oceanica horizontal rhizome growth is attributable to its extended life span and large size, which allows storage of enough carbohydrates to support growth independent of environmental conditions over a long time span (Pirc 1985, Marbà et al. 1996a). Our estimates of annual production for the 4 species were within the range of values observed elsewhere (Table 2). It is noteworthy that Zostera marina was as productive in this oligotrophic Mediterranean environment (Vidondo \& Duarte 1995) as in many relatively nutrient-richer Atlantic locations (Table 2). However, the leaf turnover rates of $C$ ymodocea nodosa, $Z$, noltii and $P$. oceanica were high and those of $Z$. marina were low in Cala Jonquet compared with other published values for these species $(1.5-2.3$ $\mathrm{yr}^{-1}$ for $P$. oceanica, of. Ott 1980, Romero $1989 ; 2.2-2.5$ $\mathrm{yr}^{-1}$ for C. nodosa, cf. Terrados \& Ros 1992, Pérez \& Romero $1994 ; 3.4 \mathrm{yr}^{-1}$ for $Z$. noltii, Vermaat et al. 1987 ; 3.1-5.3 $\mathrm{yr}^{-1}$ for Z. marina, cf. Sand-Jensen 1975, Jacobs 1979, Wium-Andersen \& Borum 1984, Van Lent \& Verschuure 1994).

The observed seasonality in production was not always conducive to a parallel biomass seasonality (Figs $2 \& 3$ ). Whereas the leaf, rhizome and root bio- mass of Zostera marina and Cymodocea nodosa showed, in agreement with previous reports (cf. SandJensen 1975, Orth \& Moore 1986, Olesen \& SandJensen 1994 for Z. marina; Peduzzi \& Vukovic 1990, Terrados \& Ros 1992, Pérez \& Romero 1994 for $C$ nodosa), maximum and minimum values during the summer and winter seasons, respectively, the leaf, rhizome and root biomass of $Z$. noltii did not display a clear seasonal pattern (Figs. $2 \& 3$ ). This result is in contrast with previous reports of $Z$. noltii biomass seasonality (Vermaat et al. 1987, Pérez 1989, PérezLlorens \& Niell 1993). That the seasonal production of $Z$. noltii in Cala Jonquet Bay is not associated with a corresponding seasonal oscillation of biomass (Figs. 2 \& 3) indicates that this production must be rapidly lost either to herbivores or as detritus, which is in agreement with reports of the limited capacity of $Z$. noltil rhizomes as storage organs (Dawes \& Guiry 1992). In fact, whereas the peak of leaf-blade shedding by senescence of $Z$. marina and $C$. nodosa was observed 1 mo after the peak of leaf-blade production, these peaks coincided for $Z$ noltii (Fig. 2), which further supports the tight temporal coupling between production and losses for this species. This results in a relatively fast leaf turnover rate $\left(9.4 \mathrm{yr}^{-1}\right.$, Table 1)

Our estimates of leaf-blade residual loss include both the consumption of living leaf biomass by herbivores and the generation of detrital leaf material as fragments torn off by wave or herbivore action. Only for Posidonia oceanica has the consumption by herbivores 
been directly estimated. Yet, for the 3 other species, an indication of herbivore contribution, both through consumption and sloughing of distal leaf parts, to total residual leaf loss can be obtained by comparing the frequency of leaves showing a bite mark at their tip with those showing only signals of wave breakage. Hence, herbivores must be responsible for most of the leaf-blade residual loss of Cymodocea nodosa and Zostera noltii because more than $75 \%$ of their leaves sampled at any date ended in a bite mark, unlike $P$. oceanica, which had negligible consumption rates, and Z. marina, for which the frequency of bitten leaves never amounted to more than $5 \%$ at any sampling time. The low herbivore pressure on $P$. oceanica in Cala Jonquet suggested by these results seems to be a general feature of the ecology of $P$. oceanica (Cebrián et al. 1996a), even though herbivory can be intense in certain locations during particular seasons (Kirkman \& Young 1981, Nedelec et al. 1981). Similarly, the low herbivory suggested on this Mediterranean population of $Z$. marina is in accordance with previous results for Atlantic populations (about $5 \%$ of the leaf production removed by herbivores, Wilkins 1982, Nienhuis \& Groenendijk 1986). The higher herbivore pressure on $C$. nodosa and $Z$. noltii suggested by our data is also consistent with previous reports of herbivory on these species elsewhere 25 to $50 \%$ of leaf production removed for $Z$. noltii in the Dutch Wadden Sea, Jacobs et al. 1981, Vermaat \& Vehagen $1996 ; 0.5$ to $43 \%$ for $C$. nodosa along the Spanish Mediterranean coast, Cebrián et al. 1996b).

Although our results strongly suggest contrasting herbivory among the 4 species sampled, they show that most leaf production was channelled as detritus, which is consistent with previous results for other seagrass species and highlights the importance of the detrital trophic route in seagrass meadows (Thayer et al. 1984. Hemminga et al. 1991, Klumpp et al. 1993, Cebrián \& Duarte 1995, Duarte \& Cebrián 1997). Other trophic routes, such as herbivory on epiphytes (Klumpp et al. 1992, Klumpp et al. 1993, Jernakoff et al. 1996), may contribute substantially to the fueling of food webs in seagrass meadows as well. Overall, the existing literature points to detritivory as the main trophic route within seagrass meadows, because epiphytes normally contribute about $40-50 \%$ to total meadow primary production and channel about $40 \%$ of their production to herbivores (cf. review by Jernakoff et al. 1996), in contrast with seagrasses, which contribute most of the rest but in general lose only $10 \%$ of their production to herbivores (cf. review by Thayer et al. 1984), the greater fraction of total meadow production being then available for detritivores. Yet more research is needed to accurately assess the routes through which primary production is
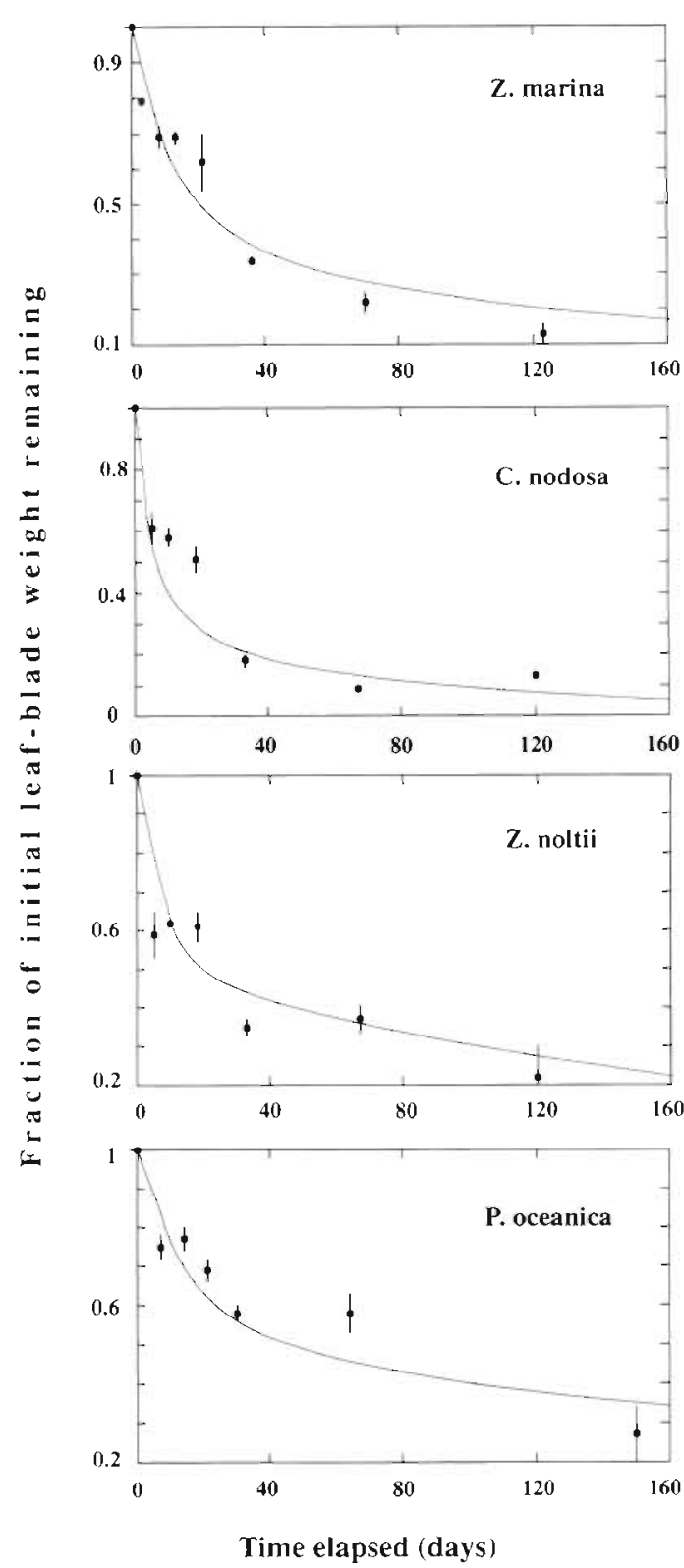

Fig. 4. Zostera marna, Cymodocea nodosa, Z. noltii and Posidonia oceanica. Weight loss during decomposition of the leafblades in the litter bag experiment. Line depicts the fitted negative exponential equation

transferred to higher trophic levels within seagrass meadows

We obtained a minimum estimate of the annual trophic flux from seagrass leaf blades to decomposers by multiplying the annual production of detrital leafblades and the fraction decomposed annually (Fig. 5), assuming a steady state in the standing biomass of detrital leaf blades (Olson 1963). The annual production of detrital leaf blades by Posidonia oceanica and Zostera marina is roughly equal to the annual leaf 
Table 2. Zostera marina, Cymodocea nodosa, Z. noltii and Posidonia oceanica. Publıshed leaf, rhizome and root production values (g DW $\mathrm{m}^{-2} \mathrm{yr}^{-1}$ ). Where published values were in grams carbon and in grams AFDW (ash-free dry weight), they have been divided by 0.4 and 0.8 , respectively, to be converted into DW (Wium-Andersen \& Borum. 1984, Hillman et al. 1989, Pedersen \& Borum 1993, Van Lent \& Verschuure 1994)

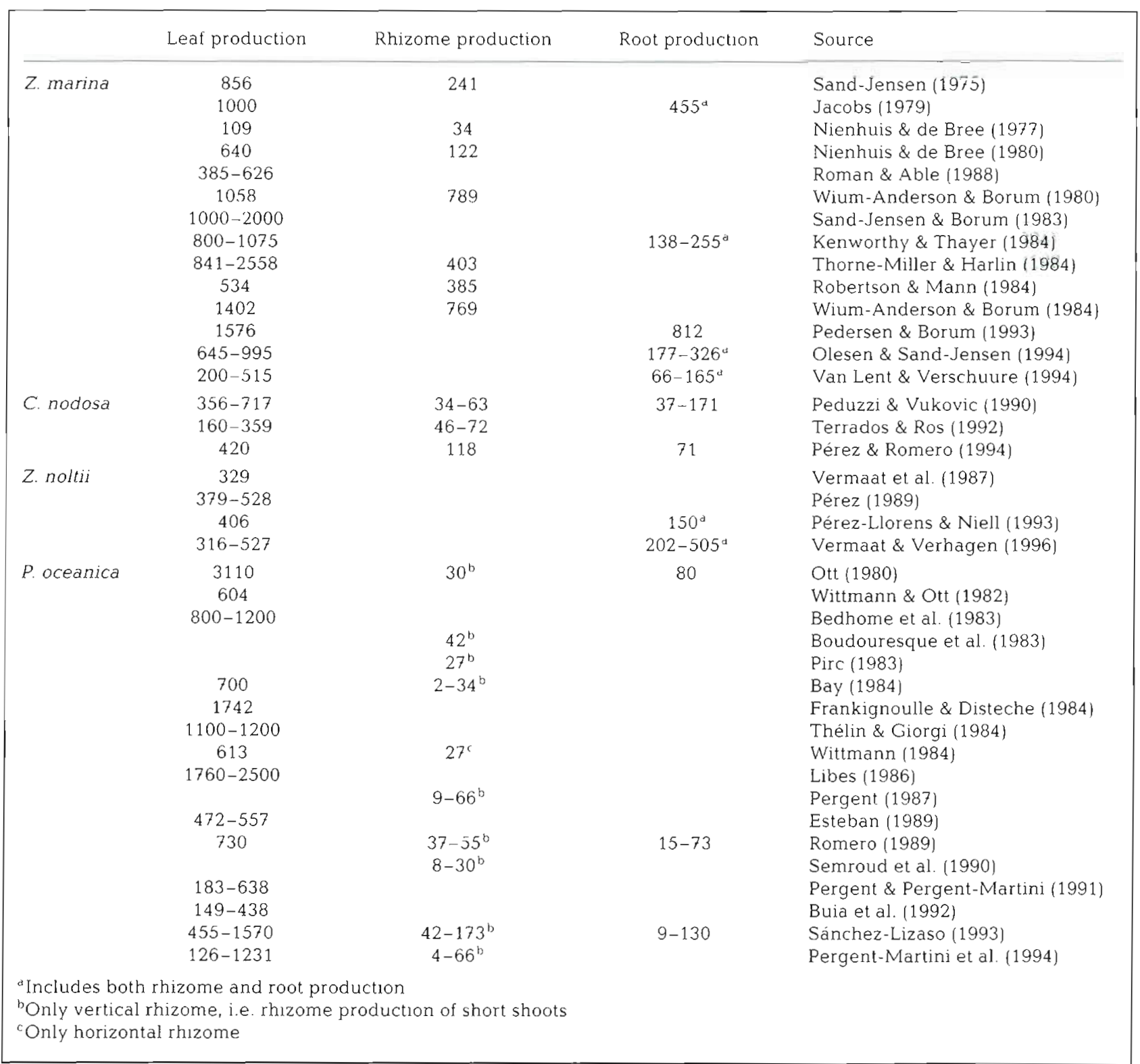

blade production, since no significant net increment of leaf biomass is observed over the sampling year (Fig 2) and herbivory is negligible. The annual production of detrital leaf-blades by Cymodocea nodosa and $Z$. noltij has been assumed to equal the annual leaf blade production shed after senescence plus half of the annual leaf-blade residual loss. The assumption that $50 \%$ of the residual loss corresponds to detrital production represents a best guess and yet has little effect on our estimates of detrital leaf-blade production since leaf-blade shedding by senescence is always much higher than the residual leaf-blade loss (Table 1). The fraction of detrital leaf-blade production decomposed annually was derived from the decay rates obtained from May to October (see 'Methods'), thereby ignoring the seasonal variability in the decay rates of seagrass leaves (Harrison 1989, Romero et al. 1992). Yet, because most of the total annual leaf-blade shedding by senescence, which accounts for most of the detrital leaf production (see 'Results'), and subsequent decay occur during the period covered by our decay experiment, we believe that our estimates are representative 

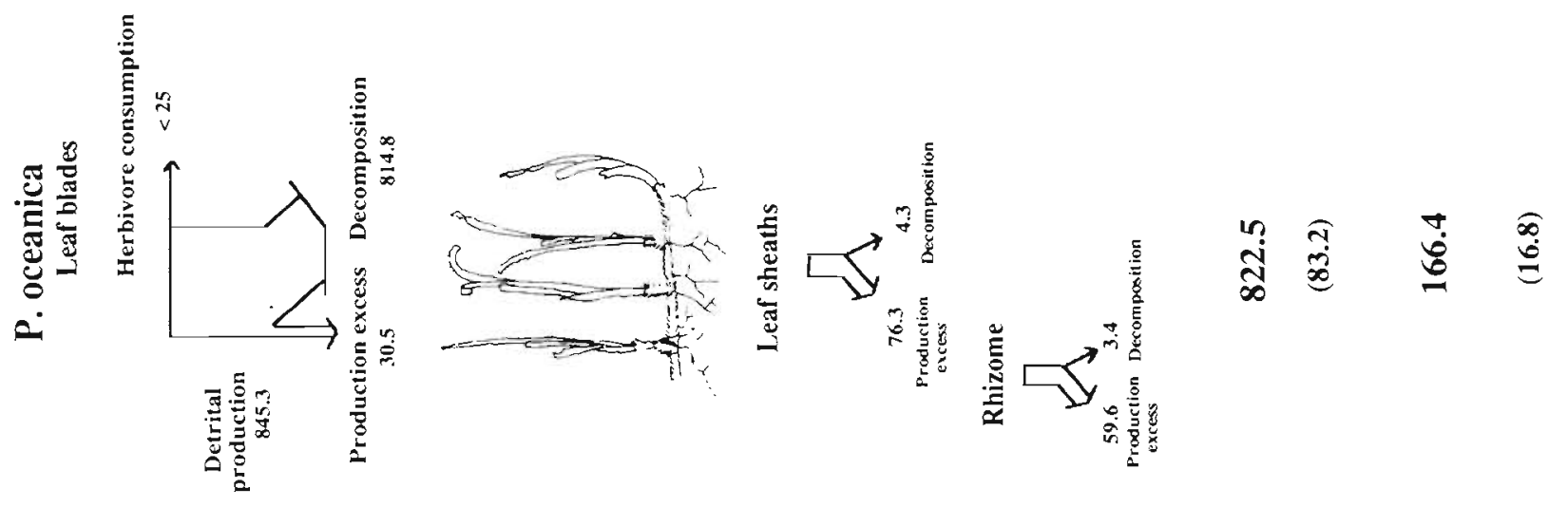

$\Xi$

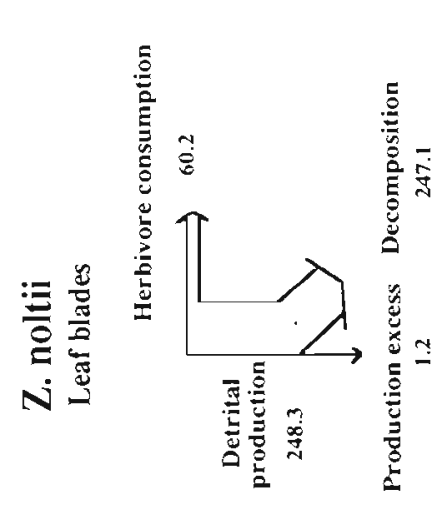

(2)
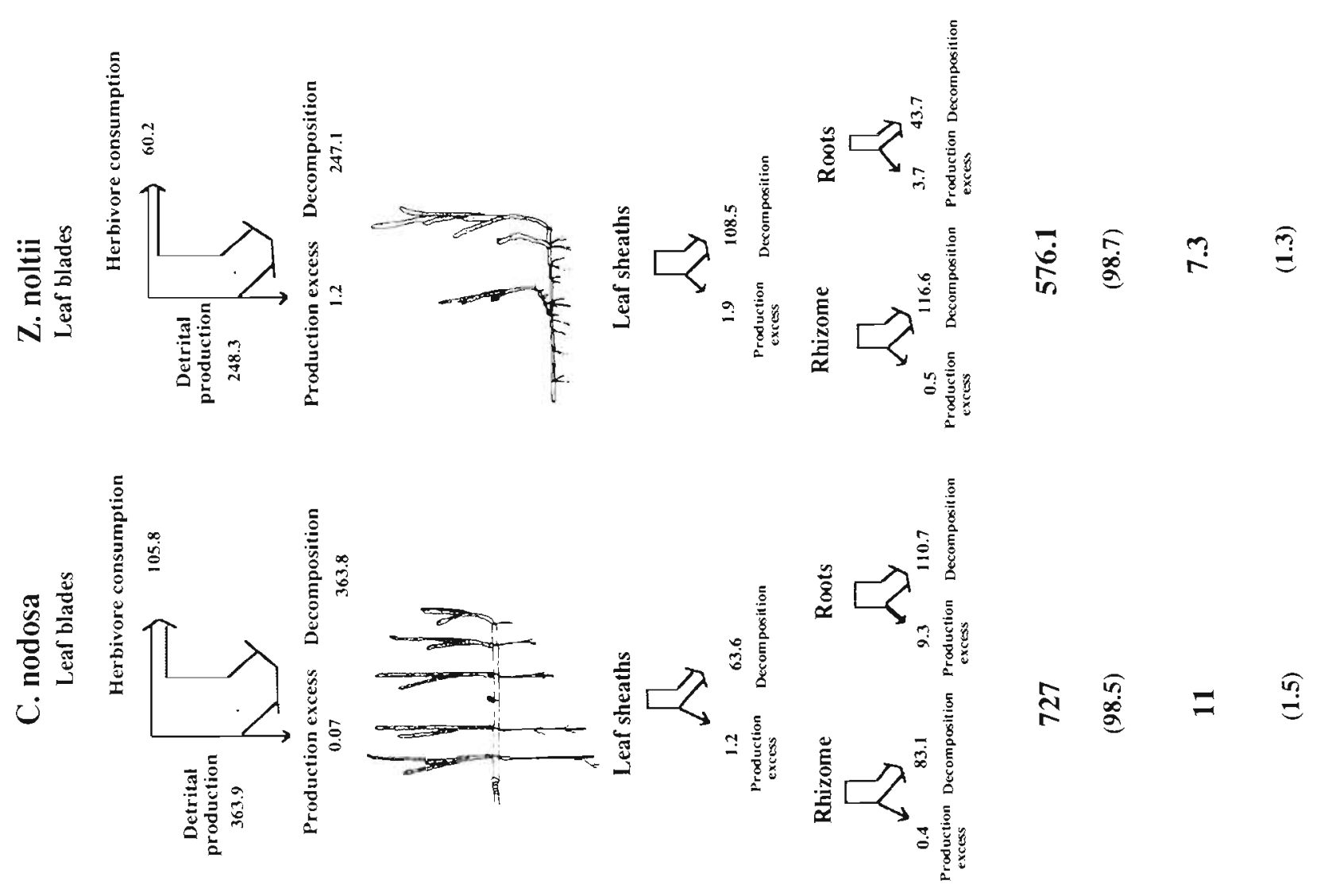

要 $=$

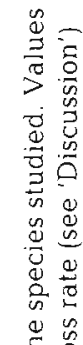

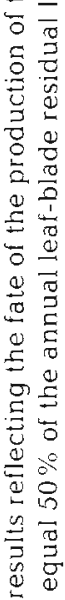

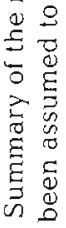

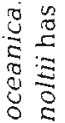

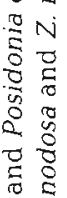

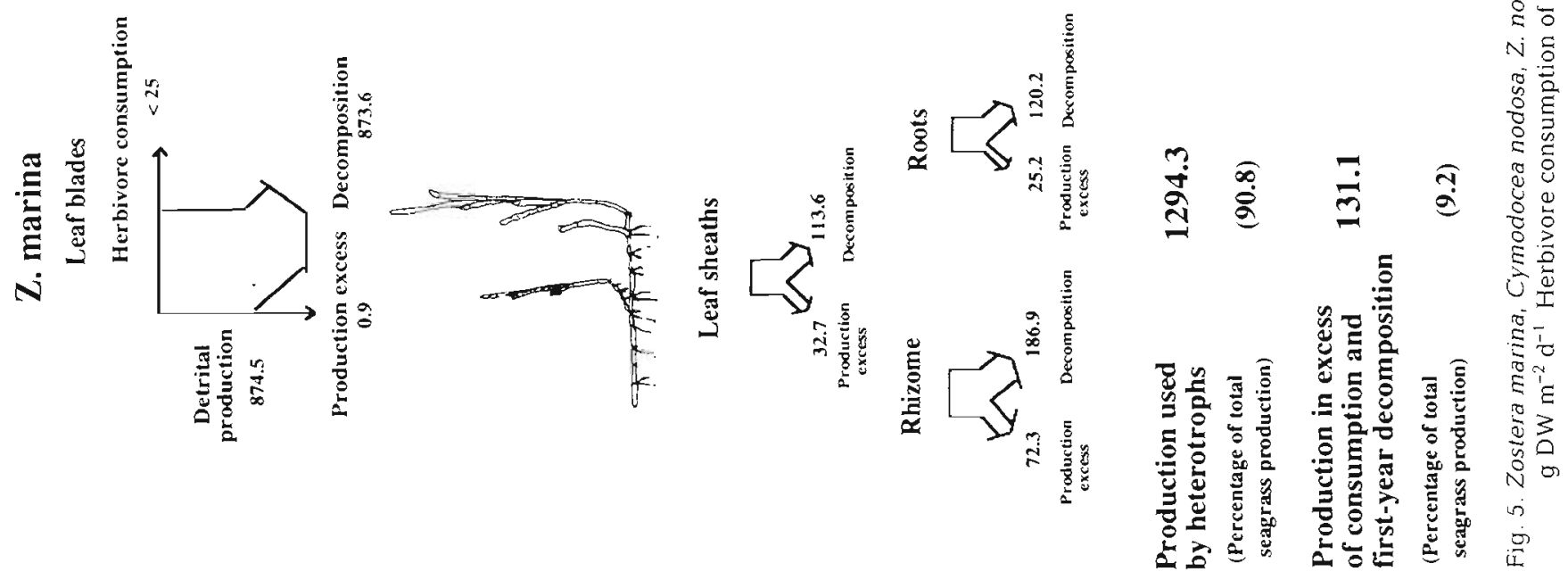


of the fraction of detrital leaf-blade production decomposed annually, Moreover, because the seasonal variability in decay rates is ignored for the 4 species, our estimates must be indicative of the existing differences in the flux from detrital leaf blades to decomposers among the 4 species.

Likewise, the belowground material (i.e leat sheaths, rhizomes and roots) available to decomposers must equal the annual belowground production, since no significant increment in belowground biomass over the sampling year occurred for any of the species (Fig 3) and herbivory on their belowground parts is thought to be negligible (Bailesteros et al. 1989). The decay rates of belowground material, which allowed a minimum estimate of the fraction of detrital belowground production which is decomposed annually under the assumption of steady state in the standing belowground detrital biomass, were derived from the literature $\left(0.0035\right.$ and $0.0048 \mathrm{~d}^{-1}$ for rhizomes and roots of Zostera marina, respectively, Kenworthy \& Thayer $1984 ; 0.015$ and $0.007 \mathrm{~d}^{-1}$ for rhizomes and roots of Cymodocea nodosa, respectively, Mateo 1995; the decay rates of the leaf sheaths of these 2 species were assumed to be the mean value between the rhizome and root decay rates; $0.00015 \mathrm{~d}^{-1}$ for all the belowground components of Posidonia oceanica, Mateo $1995)$. For $Z$. noltii, we assumed the same decay rates as for $C$. nodosa, because they grow in a heterospecific meadow (Fig. 1), and are therefore subject to very similar abiotic conditions which influence decomposition, and because the nutrient content of their belowground parts was relatively similar (Enríquez, Duarte, Marbà $\&$ Cebrián unpubl data). The use of decay rates measured in other environments introduces some variability in our estimates of annual decomposition in Cala Jonquet. Although comparisons of decomposition rates of a given seagrass species among different environments are scarce, this variability seems to lie well below $50 \%$ of the average decomposition rate (Harrison 1989, Mateo 1995), provided equality in the methodological conditions (i.e. mesh size of the litterbag and fresh/dry state of the detrital material treated) In spite of considering a variability of $50 \%$ around the values of decay rates used, the estimated differences among the 4 species in the amount of production decomposed and the main conclusions reached in this paper (see below) are not altered significantly.

Hence, we believe that our estimates of the trophic flux from seagrass detritus to decomposers, albeit only approximate, are indicative of the existing differences among the 4 species. Moreover, the underestimation of root production entailed by the methods employed (see 'Methods') can little affect our calculation of trophic flux to decomposers because root production only accounts for a minor fraction of seagrass production (Table 2). The estimated seagrass production used annually by decomposers varies by 2.5 times among species, from $515.9 \mathrm{~g} \mathrm{DW} \mathrm{m}^{-2} \mathrm{yr}^{-1}$ for the least productive species Zostera noltii to $1294.3 \mathrm{~g} \mathrm{DW} \mathrm{m}^{-2} \mathrm{yr}^{1}$ for the most productive species $Z$. marina. Hence our results indicate that the most productive species in Cala Jonquet Bay, i.e. Z. marina and Posidonia oceanica, may support about 2 to 3 times the detritivore production supported by the least productive ones, i.e. Cymodocea nodosa and $Z$. noltii, assuming a similar detritivore growth efficiency. In contrast, our results suggest these latter species transfer a greater trophic flux of leaf production to herbivores (Fig. 5), and may, therefore, maintain a higher herbivore production than $Z$. marina and $P$. oceanica, assuming a similar herbivore growth efficiency.

Seagrass production not eaten by herbivores nor decomposed by detritivores during the first year represents an upper limit of the production buried as refractory detritus, which in turn corresponds to production lost for heterotrophic use and thus points to the seagrass' capacity as a sink for organic carbon. Diagenetic losses will act upon the excess of production over consumption and decomposition during the first year and long-term accumulation of seagrass carbon will be only a tiny fraction of this production excess (Middelburg et al. 1993). Still, these estimates should be indicative of the differences in the burial of refractory detritus among the 4 species, provided the differences in long-term decay rates among the species are taken into account. The production excess over consumption and decomposition during the first year is over 1 order of magnitude higher for the most productive species (Zostera marina and Posidonia oceanica) in relation to the least productive ones (Cymodocea nodosa and $Z$. noltii; Fig. 5). On a long-term scale, however, the differences in the production stored as refractory material between $P$. oceanica and the other 3 species will certainly be more pronounced, since long-term decay rates for $P$. oceanica are slower (Pergent et al. 1994, Mateo 1995). Yet, these estimates suggest that $Z$. marina should bury higher amounts of refractory detritus than $C$. nodosa and $Z$. noltii, with $Z$. marina acting, therefore, as a greater sink for carbon in relation to the other 2 species, assuming similar long-term decay rates. Moreover, our estimates of production excess represent a lower percentage of the total production of $C$. nodosa and $Z$. noltii (about $1.5 \%$ ) in relation to the percentage represented for $Z$. marina $(9.2 \%)$ and $P$. oceanica $(16.8 \%)$, further pointing to the limited capacity of $C$. nodosa and $Z$. noltii as sinks for refractory carbon (Fig. 5). Instead, heterotrophs consume virtually all the production of $C$. nodosa and $Z$. noltii (Fig. 5), pointing to fast production recycling 
We show that the trophic flux of seagrass production to secondary consumers, for the 4 species sampled in Cala Jonquet Bay, increases with the magnitude of seagrass production, with decomposition by detritivores being remarkably dominant over consumption by herbivores for the 4 species (Fig. 5). The excess of production over consumption and first-year decomposition is also higher for the most productive species These results, along with the inferences on the potential secondary production sustained and the capacity to bury refractory detritus by the 4 Western Mediterranean seagrass species, are restricted to Cala Jonquet Bay and cannot be extrapolated to other Mediterranean locations since the levels of production reached by these species may vary widely (Table 1) and Zostera marina is almost non-existent elsewhere in the Mediterranean. However, our results are indicative of marked differences in the fate of production among the 4 Mediterranean seagrass species growing in Cala Jonquet Bay which are independent of differences in the level of production reached. Namely, the variability found in herbivore contribution to the total flux of seagrass production to secondary consumers and, then, herbivore pressure on seagrass production (i.e. percentage of seagrass production consumed by herbivores) seems instead associated with differences in the leaf turnover rate, the species with the highest leaf turnover rates (i.e. $Z$, noltii and Cymodocea nodosa) losing a greater percentage of their production to herbivores. This is in agreement with the tendency for the percentage of leaf production removed by herbivores to increase with the leaf turnover rate found among seagrass species (Cebrián 1996). This tendency should result from the lower levels of lignin and higher levels of carbohydrates typically found in the leaves of fastergrowing species (cf. Cebrian 1996), which would render them more palatable for herbivores and would thus entail herbivore preference for them. The association between the percentage of leaf production consumed and turnover rate has also been found at a general scale comparing different types of primary producers (Cebrián \& Duarte 1994) and has also been justified on the basis of a higher trophic quality of faster-growing plants. Moreover, the similarity among the estimates of herbivory on these 4 species registered in very different locations (for instance, herbivory on $Z$. marina and Z. noltii in Atlantic populations and in Cala Jonquet Bay, and that on Posidonia oceanica in contrasting environments along the Spanish coast) suggests that herbivory variability among seagrass species may be linked to differences in species-specific properties with implications on the seagrass trophic value, such as the leaf turnover rate, apart from being also influenced by environmental variability (Cebrián et al 1996b).
Our results also suggest that seagrass species with a lower leaf turnover rate could accumulate larger pools of refractory detritus, provided there is variability in long-term decay rates among species, because the percentage of production escaping from consumption by herbivores and first-year decomposition by detritivores is higher for the sampled species with lower leaf turnover rates. This hypothesis is supported by the large pools of refractory detritus observed for seagrass species with relatively slow-growing leaves, for instance Posidonia oceanica (Romero et al. 1994, Mateo 1995), Posidonia australis (Shepherd \& Sprigg 1976) or Thalassodendron sp. (Lipkin 1979), in comparison with the much smaller pools supported by other species with faster-growing leaves, such as Cymodocea nodosa (Mateo 1995), Zostera marina (Kenworthy \& Thayer 1984, Pellikaan \& Nienhuis 1988) or Thalassia testudinum (Kenworthy \& Thayer 1984), which could result from the lower decay rates, probably associated with higher lignin content, of the former species (Kenworthy \& Thayer 1984, Harrison 1989). This hypothesis is further in agreement with the general dependence of the size and turnover of the plant detrital pool on plant turnover rate for aquatic and terrestrial plant communities (Cebrián \& Duarte 1995). Hence we suggest that, whereas the magnitude of production reached by a seagrass species should be indicative of the amount of the total secondary production (herbivores + detritivores) maintained by the seagrass, differences in the leaf turnover rate among species should help explain differences in the percentage of production consumed by herbivores and in the percentage of detrital production recycled or buried as refractory detritus. On this basis, species with faster-growing leaves would transfer greater percentages of production to herbivores and recycle most of the residual detrital production, thereby storing relatively smaller refractory detrital pools, in comparison with species with slower-growing leaves. This hypothesis, if confirmed, should imply that herbivores and detritivores, through consumption of photosynthetic material and recycling of detrital material, respectively, must have a greater impact on the production dynamics of fastergrowing seagrass species compared with slower-growing species.

Acknowledgements. This work was founded by the Cl1" CT91-0952 project from the Commission of the European Communities. J.C. was supported by a fellowship from the CIRIT (Comissio Interministerial de Recerca i Tecnologia) and S.E. by a fellowship from the CICYT (Comision Interministerial de Ciencia y Tecnología). We thank. J. Romero and several anonymous referees for useful comments on the manuscript, and $C$. Sunyé and his tamily for providing access to the field site and hospitality. We are also grateful to $\mathrm{T}$ Alcoverro, L. Marbà and M. Gallegos for field assistance. 


\section{LITERATURE CITED}

Alcoverro T, Duarte CM, Romero J (1995) Annual growth dynamics of Posidonia oceanica: contribution of largescale versus local factors to seasonalıty. Mar Ecol Prog Ser 120:203-210

Bach S, Thayer G, LaCroix M (1986) Export of detritus from eelgrass (Zostera marina) beds near Beaufort, North Carolina, USA. Mar Ecol Prog Ser 28:265-278

Ballesteros E, Ros JD, Flos J, Margalef R (1989) Els ecosistemes bentònics. In: Folch $\mathrm{R}$ (ed) História naturals dels països Catalans. Sistemes naturals. Fundació Enciclopedia Catalana, Barcelona, p 119-176

Bay D (1984) A field study on the growth dynamics and productivity of Posidonıa oceanica (L.) Delile in (alvi Bay, Corsica. Aquat Bot 20:33-42

Bedhome HL, Thelin I, Boudouresque CF (1983) Mesure de la production primaire des feuilles de Posidonia oceanica: modifications de la méthode de Zieman. Bot Mar 26:35-43

Boudouresque CF, Meinesz A, Pergent G (1983) Mesure de la production annuelle des rhizomes dans l'herbier à Posidonia oceanica à Port-Cros (Var) et Galeria (Corse). Rapp RV Réun Comm Int Explor Sci Mer Médit 28:135-136

Buia MC, Zupo V, Mazzella L (1992) Primary production and growth in Posidonia oceanica. PSZN I: Mar Ecol 13:2-16

Cebrián J (1996) The fate of autotrophic production with special reference to herbivory: from seagrasses to some generral patterns among plant communities. PhD thesis, Universidad Politécnica de Cataluña, Barcelona

Cebrián J, Duarte CM (1994) The dependence of herbivory on growth rate in natural plant communities. Funct Ecol 8 $518-525$

Cebrián J, Duarte CM (1995) Plant growth-rate dependance of detrital carbon storage in ecosystems. Science 268: $1606-1608$

Cebrián J, Duarte CM, Marbà N (1996b) Herbivory on the seagrass Cymodocea nodosa (Ucria) Ascherson in contrasting Spanish Mediterranean habitats. J Exp Mar Biol Ecol 204:103-111

Cebrián J, Duarte CM, Marbà N, Enríquez S, Gallegos M Olesen B (1996a) Herbivory on Posidonla oceanica (L.) Delile: magnitude and variability in the Spanish Mediterranean. Mar Ecol Prog Ser 130:147-155

Dawes CJ, Guiry MD (1992) Proximate constituents in the seagrass Zostera manna and $Z$. noltii in Ireland: seasonal changes and the effect of blade removal. PSZN I: Mar Ecol 13:307-316

De longh $\mathrm{HH}$, Wenno BJ, Meelis E (1995) Seagrass distribution and seasonal biomass changes in relation to dugongs grazing in the Moluccas. East Indonesia. Aquat Bot 50 $1-21$

Duarte CM (1989) Temporal biomass variability and production/biomass relationships of seagrass communities. Mar Ecol Prog Ser 51:269-276

Duarte CM, Cebrian J (1997) The fate of marine autotrophic production. Limnol Oceanogr 41:1758-1766

Duarte CM, Marbà N, Agawin N, Cebrián J, Enríquez S, Fortes MD, Gallegos ME, Menno M, Olesen B, SandJensen K, Uri J, Vermaat $J$ (1994) Reconstruction of seagrass dynamics: age determinations and associated tools for the seagrass ecologist. Mar Ecol Prog Ser 107:195-209

Esteban JL (1989) Dinámica, ciclo de hojas y producción foliar en praderas de Posidonia oceanica del litoral de la Comunidad Valenciana. MSc thesis, Universidad de Valencia

Frankignoulle $\mathrm{M}_{1}$. Disteche A (1984) $\mathrm{CO}_{2}$ chemistry in the water colum above a Posidonia oceanica seagrass bed and related air-sea exchanges. Oceanol Acta 7:209-219
Harnson PG \{1989) Detrital processing in seagrass systems: a review of factors affecting decay rates, remineraluzation and detritivory, Aquat Bot 23:263-288

Hemmingla $M A$, Harrison $P G$, van Lent $F$ (1991) The balance of nutrient losses and gains in seagrass meadows. Mar Ecol Prog Ser 71:85-96

Hillman K, Walker DI, Larkum AWD, McComb AJ (1989) Productivity and nutnent limitation. In: Larkum AWD, McComb A.J. Shepherd SA (eds) Biology of seagrasses A treatise on the biology of seagrasses with special reference to the Australian region. Elsevier, Amsterdam p 635-685

Jacobs R (1979) Distribution and aspects of the production and biomass of eelgrass Zostera manna L., at Roscoff, France. Aquat Bot 7:151-172

Jacobs R, den Hartog C, Braster C, Carrière F (1981) Grazing of the seagrass Zostera noltii by birds at Terschelling (Dutch Wadden Sea). Aquat Bot 10:241-259

Jernakoff P, Brearley A, Nielsen J (1996) Factors affecting grazer-epiphyte interactions in temperate seagrass meadows. Oceanogr Mar Biol Annu Rev 34:109-62

Josselyn MN, Fonseca M. Niesen T, Larson R (1986) Biomass. production and decomposition of a deepwater seagrass, Halophila decipiens Ostenfeld. Aquat Bot 25:47-61

Kenworthy J, Thayer G (1984) Production and decomposition of the roots and rhizomes of seagrasses, Zostera marina and Thalassia testudinum, in temperate and subtropical marine ecosystems. Bull Mar Sci 35:364-379

Kurkman $H$, Young $P$ (1981) Measurement of health and echinoderm grazing on Posidonia oceanica (L.) Delile. Aquat Bot 10:329-338

Klumpp DW, Salita-Espinosa J, Fortes MD (1992) The role of epiphytic periphyton and macroinvertebrate grazers in the trophic flux of a tropical seagrass community. Aquat Bot 43:327-349

Klumpp DW, Salita-Espinosa JS, Fortes MD (1993) Feeding ecology and trophic role of sea urchins in a tropical seagrass community. Aquat Bot 45:205-229

Libes M (1986) Productivity-irradiance relationship of Posidonia oceanica and its epiphytes. Aquat Bot 26:285-306

Lipkin Y (1979) Quantitative aspects of seagrass communities, particularly of those dominated by Halophila stipulacea, in Sinai (Northern Red Sea). Aquat Bot 7:119-128

Marbà N, Cebrián J, Enriquez S, Duarte CM (1996a) Growth patterns of Western Mediterranean seagrasses: speciesspecufic responses to seasonal forcing. Mar Ecol Prog Ser 133:203-215

Marbà N, Duarte CM. Cebrián J, Gallegos ME, Olesen B, Sand-Jensen K (1996b) Growth and population dynamics of Posidonia oceanica on the Spanish Mediterranean coast: elucidating seagrass decline. Mar Ecol Prog Ser 137: $203-213$

Mateo MA (1995) El compartimento detrítico en ecosistemas de fanerógamas mannas mediterráneas. $\mathrm{PhD}$ thesis, Universidad de Barcelona

Middelburg JJ, Vlug T, van der Nat F (1993) Organic matter mineralızation in marine systems. Global Planet Change $8: 47-58$

Nedelec H, Verlaque $M$, Diapoulis A (1981) Preliminary data on Posidoma consumption by Paracentrotus lividus in Corsica (France). Rapp PV Réun Comm int Explor Sci Mer Médit 27:203-204

Nienhuis PH, de Bree B (1977) Production and ecology of eelgrass (Zostera marina L.) in the Grevelingen estuary, The Netherlands, before and after the closure. Hydrobiologia 52:55-66

Nienhuis $\mathrm{PH}$, de Bree B (1980) Production and growth 
dynamics of eelgrass (Zostera marina L.) in brackish Lake Grevelingen (The Netherlands). Neth J Sea Res 14: $102-118$

Nienhuis $\mathrm{PH}_{1}$ Groenendijk A (1986) Consumption of eelgrass (Zostera marina) by birds and invertebrates: an annual budget. Mar Ecol Prog Ser 29:29-35

Olesen B, Sand-Jensen K (1994) Demography of shallow eelgrass (Zostera marina) populations-shoot dynamics and biomass development. J Ecol 82:379-390

Olson JS (1963) Energy storage and the balance of producers and decomposers in ecological systems. Ecology 44 : $322-331$

Orth RJ, Moore KA (1986) Seasonal and year-to-year variations in the growth of Zostera marina L. (eelgrass) in the lower Chesapeake Bay. Aquat Bot 24:335-341

Ott J (1980) Growth and production in Posidonia oceanica (L.) Delıle. PSZN I: Mar Ecol 1:47-64

Ott J, Maurer L (1977) Strategies of energy transfer from marine macrophytes to consumer levels: the Posidonia oceanica example. In: Keegan B (ed) Biology of benthic organisms. Pergamon Press, Oxford, p 493-502

Pedersen MF, Borum J (1993) An annual nitrogen budget for a seagrass Zostera marina population. Mar Ecol Prog Ser 101:169-177

Peduzzi P, Vukovic A (1990) Primary production of Cymodocea nodosa in the Gulf of Treste (Northern Adriatic Sea): a comparison of methods. Mar Ecol Prog Ser 64:197-207

Pellikaan G, Nienhuis PH (1988) Nutrient uptake and release during growth and decomposition of eelgrass, Zostera marina L., and its effect on the nutrent dynamics of Lake Grevelingen. Aquat Bot 30:189-214

Pérez M (1989) Fanerógamas marinas en sistemas estuáricos: producción, factores limitantes y algunos aspectos del ciclo de nutrientes. $\mathrm{PhD}$ thesis, Universidad de Barcelona

Pérez M, Romero J (1994) Growth dynamics, production and nutrent status of the seagrass Cymodocea nodosa in a Mediterranean semi-estuarine envıronment. PSZN I: Mar Ecol 15:51-64

Pérez-Llorens JL, Niell FX (1993) Seasonal dynamics of biomass and nutrient content in the intertidal seagrass Zostera noltii Hornem. from Palmones River estuary, Spain. Aquat Bot 46:49-66

Pergent G (1987) Recherches lepidochronologiques chez Posidonia oceanica (Potamogetonaceae): fluctuations des paramètres anatomiques et morphologiques des écailles des rhizomes. PhD thesis, Université Aix-Marseille II

Pergent G (1990) Lepidochronological analysis in the seagrass Posidonia oceanica: a standardized approach. Aquat Bot 37:39-54

Pergent G, Pergent-Martini C (1991) Leaf renewal cycle and primary production of Posidonia oceanica (L.) Delile in the bay of Lacco Ameno (Ischia, Italy) using lepidochronological analyses. Aquat Bot 42:49-66

Pergent G, Romero J, Pergent-Martinı C, Mateo MA, Boudouresque CF (1994) Primary production, stocks and fluxes in the Mediterranean seagrass Posidonia oceanica. Mar Ecol Prog Ser 106:139-146

Pergent-Martini C, Rico-Raimondino V, Pergent G (1994) Primary production of Posidonia oceanica in the Mediterranean Basin. Mar Biol 120:9-15

Pirc H (1983) Belowground biomass of Posidonia oceanica (L.) Delile and its importance to the growth dynamics. Proc Int Symp Aquat Macrophytes, Nijmegen, p 177-181

Pirc H (1985) Growth dynamics in Posidonia oceanica (L.) Dellle. 1: seasonal changes of soluble carbohydrates, starch, free amino acids, nutrogen and organic anions in different parts of the plant. PSZN I: Mar Ecol 6:141-165
Robertson AI, Mann KH (1984) Disturbance by ice and lifehistory adaptations of the seagrass Zostera marina. Mar Biol 80:131-141

Roman CT, Able K (1988) Production ecology of eelgrass (Zostera marina L.) in a Cape Cod salt marsh-estuarine system, Massachusetts. Aquat Bot 32:353-363

Romero J (1989) Primary production of Posidonia oceanica beds in the Medas Islands (Girona, NE Spain). In: Boudouresque CF, Meinesz A, Fresi E, Gravez V (eds) 2nd Int Workshop on Posıdonia oceanica Beds. GIS Posidonie publ, Marseille, p 85-91

Romero J, Pérez M, Mateo MA, Sala E (1994) The belowground organs of the Mediterranean seagrass Posidonia oceanica as a biogeochemical sink. Aquat Bot 47:13-19

Romero J, Pergent G, Pergent-Martini C, Mateo MA, Regnier $C$ (1992) The detritic compartment in a Posidonia ocenica meadow: litter features, decomposition rates, and mineral stocks. PSZN I: Mar Ecol 13:69-83

Sánchez-Lisazo JL (1993) Estudio de la pradera de Posidonia oceanica (L.) Delile de la reserva marina de Tabarca (Alicante): fenología y producción primaria. PhD thesis, Universidad de Alicante

Sand-Jensen K (1975) Biomass, net production and growth dynamics in an eelgrass (Zostera marina L.) population in Vellerup Vig, Denmark. Ophelia 14:185-201

Sand-Jensen K, Borum J (1983) Regulation of growth dynamics of eelgrass (Zostera marina L.) in Danish coastal waters. Mar Technol Soc J 17:15-21

Semroud R, Mezegrane S, Soltane L (1990) Etude lepidochronologique de Posidonia oceanica dans la region d'Alger (Algérie). Données prélimindires. Rapp PV Réun Comm Int Explor Sci Mer Médit 32 B-I 15:10

Shepherd SA, Sprigg RC (1976) Substrate, sediments and subtidal ecology of Gulf St. Vicent and Investigator straits. In: Twidale CR, Tyler MJ, Webb BP (eds) Natural history of the Adelaide Regıon. R Soc S Aust, Adelaıde, p 161-174

Sheppard C, Price A, Roberts C (1992) Marine ecology of the Arabian Region: patterns and processes in extreme tropical environments. Academic Press, London

Terrados J, Ros JD (1992) Growth and primary production of Cymodocea nodosa (Ucria) Ascherson in a Mediterranean coastal lagoon: the Mar Menor (SE Spain). Aquat Bot 43: $63-74$

Thayer G, Bjorndal K, Ogden J, Williams S, Zieman J (1984) Role of larger herbivores in seagrass communities. Estuaries $7: 351-376$

Thélin I, Giorgi J (1984) Production de feuilles dans un herbier superficiel à Posidonia oceanica évaluée par un méthode dérivée de la méthode de Zıeman. In: Boudouresque CF, Jeudy de Grissac A, Olivier J (eds) 1st Int Workshop on Posidonia oceanica Beds. GIS Posidonie pub], Marseille, p 271-276

Thorne-Miller B, Harlin MM (1984) The production of Zostera marina $\mathrm{L}$. and other submerged macrophytes in a coastal lagoon in Rhode lsland, USA. Bot Mar 27:539-546

Tsokos CP (1972) Probability distributions: an introduction to probability theory with applications. Duxbury Press, Belmont

Van Lent $F$, Verschuure JM (1994) Intraspecific variability of Zostera marina L. (eelgrass) in the estuaries and lagoons of the southwestern Netherlands. I: population dynamics. Aquat Bot 48:31-58

Velimirov B (1984) Grazing of Boops salpa L. on Posidonia oceanica and utilization of its soluble compounds. In: Boudouresque CF. Jeudy de Grissac A, Olivier J (eds) 1 st Int Workshop on Posidonia oceanica Beds. GIS Posidonie publ, Marseille, p 381-387 
Vermadt JE, Hootsmans MJM, Nienhuis PH (1987) Seasonal dynamics and leaf growth of Zostera noltin Hornem., a perennial intertidal seagrass. Aquat Bot 28:287-299

Vermaat JE, Verhagen FCA (1996) Seasonal variation in the intertidal seagrass Zostera noltii Hornem: coupling demographic and physiological patterns. Aquat Bot 52:259-281

Vidondo B, Duarte CM (1995) Seasonal growth of Codium bursa, a slow-growing Mediterranean macroalga: in situ experimental evidence of nutrient limitation. Mar Ecol Prog Ser 123:185 191

Wieder RK, Lang GE (1982) A critrque of the analytical methods used in examining decomposition data obtained from litter bags. Ecology 63:1636-1642

Wilkins E (1982) Waterfowl utilization of a submerged vegetation (Zostera marina and Ruppia maritima) bed in the lower Chesapeake Bay. MSc thesis, College of William and Mary, Williamsburg, VA

This article was submitted to the editor
Wittmann KJ (1984) Temporal and morphological variations of growth in a natural stand of Posidonia oceanica (L.) Delile. PSZN I: Mar Ecol 5:301-316

Wittmann KJ, Ott JA (1982) Effects of cropping on the mediterranean seagrass Posidonia oceanica (L.) Delile. PSZN I: Mar Ecol 3:151-159

Wium-Andersen S. Borum J (1980) Biomass and production of eelgrass (Zostera marina L.) in the Øresund, Denmark Ophelia (Suppl 1):49-55

Wium-Andersen S, Borum J (1984) Biomass variation and autotrophic production of an epiphyte-macrophyte community in a coastal Danish area. I: eelgrass (Zostera manna) biomass and net production. Ophelia 23: $33-46$

Zieman JC (1982) The ecology of the seagrasses of South Florida: a community profile. US Fish Wildl Serv Biol Serv Progr FWS/OBS-82/85 124:26

Manuscript received: August 8, 1996

Revised version accepted: June 20,1997 


\section{Erratum}

Magnitude and fate of the production of four co-occurring Western Mediterranean seagrass species

Just Cebrián, Carlos M. Duarte, Nùria Marbà, Susana Enríquez

Mar Ecol Prog Ser 155: 29-44, 1997

- On page 39, an incorrect unit appeared in the legend to Fig. 5. The correct unit for the values in the figure is $\mathrm{g} \mathrm{DW} \mathrm{m}^{-2} \mathrm{yr}^{-1}$ 